\title{
How Promotional Activities and Evaluative Factors Affect Destination Loyalty: Evidence from International Tourists of Vietnam
}

\author{
Wen-Hsiang Lai ${ }^{1} \&$ Nguyen Quang Vinh ${ }^{2}$ \\ ${ }^{1}$ Graduate Institute of Management of Technology, Feng Chia University, Taichung, Taiwan \\ ${ }^{2} \mathrm{PhD}$ Program in Business, Feng Chia University, Taichung, Taiwan \\ Correspondence: Nguyen Quang Vinh, PhD Program in Business, Feng Chia University, Taichung, Taiwan. \\ Email: quangvinh191081@yahoo.com
}

\author{
Received: November 25, 2012 Accepted: December 10, 2012 Online Published: January 15, 2013 \\ doi:10.5539/ijms.v5n1p70 URL: http://dx.doi.org/10.5539/ijms.v5n1p70
}

\begin{abstract}
Tourists' expectations regarding a given destination are affected to a certain extent by the destination's promotional activities. Although tourism destinations have promotional strategies that are put into effect with the goal of increasing the number of visitors, destination promotional failures are inevitable in the tourism industry. Many of the marketing planners in Vietnam tend to encounter difficulties when deciding which promotion tools to employ because they fail to understand tourists' consumer behaviors. The main purpose of this study is to explore how promotional activities and evaluative factors affect destination loyalty within the tourism industry. This study proposes a structural model of the relationships among promotional activities (PAs), tourist expectations (TEs), tourist satisfaction (TS) and destination loyalty (DL). Randomly selected respondents from the population of international tourists departing from Vietnamese international airports were selected to participate in the questionnaire study. Initially, an exploratory factor analysis (EFA) was performed to test the validity of the constructs, and the confirmatory factor analysis (CFA), using AMOS, was used to test the significance of the proposed hypothesis model. The results show that the relationships among PA, TE,TS and DL appear significant. The results also indicate that, beside their high expectations regarding a given destination's features, international tourists seem to be dissatisfied with the services that they received when visiting Vietnam. This dissatisfaction leads to a low level of tourists' intentions to return to Vietnam. This paper concludes with a discussion of the implications of the findings from the study for tourism marketers.
\end{abstract}

Keywords: tourism promotional, tourist expectation, tourist satisfaction, destination loyalty

\section{Introduction}

Reilly (1990) indicates that tourists eventually choose their travel destinations based on images of their destinations. Pearce (1989) conceptualizes a destination as an amalgam of products and services available in one location that can draw visitors from beyond its spatial confines. Other researchers (Murphy, Pritchard and Smith, 2000) have also viewed a destination as an amalgam of individual products and opportunities for experiences that combine to form a total experience of the area visited. Hu and Ritchie (1993, p 26) define a tourism destination as "a package of tourism facilities and services, which like any other consumer product, is composed of a number of multi-dimensional attributes." In defining the nature of the tourism product, several other researchers have incorporated a supply-side and a demand-side approach that describes how multiple components of the destination interact with travelers during their trip (Gunn, 1997; Inkeeps, 1991; Lew, 1987). Molina et al (2010, p. 722) indicate that "understanding how customers acquire information is important for marketing management decisions." A promotional activity is a business activity that communicates a company's interests and embodies a transmission-reception of a variety of types of information between internal business processes and external business relationships. Modern companies have complex communication systems, which operate in various manners and through various feedback mechanisms. In researching tourists' expectations, scholars use information regarding tourists' opinions of a destination before they visit said destination (Gursoy and McCleary, 2004; Um and Crompton, 1990; Molina et al, 2010). Therefore, the destination is defined as not only the perceptions of individual destination attributes but also the holistic impression made by the destination through promotional activities (PAs). Referring to a destination's attributes and promotional activities, Dann (1977) uses the pull factors (such as landscape, culture, price, service and climate)as the composite destination 
attribute "attractiveness", which have the ability to pull travelers to some of the supply-side components such as attractions or destination PAs. In other words, the pull factors can lead an individual traveler to select one destination over another once the decision to travel has been made. In this context, if tourists lack information regarding a specific destination, they can find such information from magazines, celebrities (opinion leaders), television and the Internet, which will ultimately influence their tourism expectations (TEs) of the destination (Wang and Fesenmaier, 2005; Govers, Go and Kumar, 2007).

Vietnam is becoming a popular tourist destination in the Asia-Pacific region, and its tourism industry has grown enormously over the past few years (Bui,2011). In 2009, Vietnam was ranked fifth of 143 nations on the "Happy Planet" index calculated by the New Economics Foundation (NEF) in the UK. Vietnam's advantages include its political stability, lack of terrorism threats or active religious and ethnic conflicts and its image as a "new" destination in the world(NEF, 2009). Areport titled "Vietnam Tourism Industry Forecast to 2012" from the Vietnam Research and Market Organization in 2009 shows that the tourism industry in Vietnam is set for stupendous growth in the coming years. Owing to the PAs of the government to boost tourism as a whole and to specifically increase the level of meetings, incentives, conferences, and exhibitions (MICE)tourism, the tourism industry proceeds in Vietnam are expected to reach US\$ 8.7 billion by 2013 and are expected to do so through double-digit annual growth rates beginning in 2010. Vietnam is ranked as having the fourth-fastest rate of growth for inbound tourism in the world. The main driving factors of this growth over the forecasted period are the government's efforts to increase inbound tourism, Vietnam's improvement of consumer's confidence and the high demand for promotional offers provided by travel and tourism suppliers.

Promotion is recognized by many as a critical element in tourism marketing. To concretely understand the real efficiency of promotional activities in terms of tourist evaluations from their satisfaction with and destination loyalty for Vietnam, an examination of the influence of overall total satisfaction (TS) and the level of satisfaction with specific attributes and their impacts on repeat visitation to Vietnam has been conducted in Truong's (2005) study. However Truong (2005) notes that changes need to be made in the promotional strategy for Vietnam, and Weber (1996) and Cho (1998) have shown that many studies concentrate on tourist needs, but few focus on promotional activities and tourist satisfaction with the attributes of a specific destination area or on the perceived needs of tourists and their satisfaction with the outcomes of their needs. Most studies (Ahmad Puad et al, 2011; Chi and Qu, 2008; Chen and Tsai, 2007; Mahadzirah et al, 2011) focus on tourist satisfaction and destination loyalty by examining the influence of overall travel satisfaction on destination loyalty. However, there is a dearth of studies that attempt to examine the links among promotional activities, tourist expectation, tourist satisfaction and destination loyalty; especially within the Vietnamese tourism industry for the purpose of integrating information technologies along with interactive marketing activities to serve tourists properly and compete in tourism markets successfully.

Due to the lack of relevant previous studies, the main purpose of the present study is to examine the empirical evidence on the causal relationship between tourist satisfaction and destination loyalty. Therefore, a research model of the effects of promotional activity and tourist expectation on tourist satisfaction and destination loyalty was proposed and tested. This study aims to help tourism planners and marketers to construct a foundation of knowledge and understanding on which to base their strategic marketing decisions in combining conventional marketing planning and methods of handling relations with tourists and destination in order to enable the establishment of interactive relations as well as attract international visitors.

\section{Literature Review}

\subsection{The Relationship among Promotional Activities, Tourist Expectation, Satisfaction and Loyalty}

The promotional activity that the Vietnamese government has adopted to promote its tourism industry is intended to introduce the country's image to international visitors. Robin et al (2002) observe that the marketing of tourism destinations has traditionally been heavily oriented toward promotional activity. However, Poon (1993) demonstrates that destination marketing may achieve greater success by focusing on improving destination competitiveness, which implies that the needs of both destinations and stakeholders should occupy a more strategic perspective in tourism planning, development and marketing. At present, the marketing activities conducted by destination marketing organizations are centered mainly on the promotion of the destination as a whole (Lewis et al, 1995; Gomezlj and Mihalic, 2008). The method of promotion refers to the means used to implement promotional activities and includes promotional tools, information channels and promotional programs. Kotler et al (1993) define a "promotional strategy" as the activity of communication with the target audience in a market (or multiple different markets). Various modes of promotional strategies and tools exist, including sales promotions, direct selling, advertising, public relations, and personal selling. Baloglu and 
Mangaloglu (2001) note that the main information sources used in executing promotional activities include formal interpersonal sources, external formal sources, commercial sources, and professional sources. Buhalis (1998) points out the importance of Internet as a source of information for consumers to become familiar with this emerging world of information. Thus, the term "information source" refers to the channel for providing information regarding the destination attributes.

Truong and King (2009) demonstrate that the tourism attributes defined as the key characteristics of a given holiday destination may be conveniently grouped under the heading "The Five A's": attractions, activities, accessibility, accommodations and amenities. Dann (1981, p. 207) indicates that "once the trip has been decided upon, where to go, what to see or what to do (relating to the specific destinations) can be tackled. Thus, analytically, and often both logically and temporally, push factors precede pull factors." Tourists are pushed by their need to decide "whether to go", and then the tourists are pulled by destinations" attributes to decide "where to go". Therefore, promotional activityis very important for a destination to be successful in attracting more tourists. Bologlu and Mangalolu (2001) note that tour operators and travel agents have multiple and critical functions in the tourism market because they provide information and influence on tourism expectations and perceptions. Within the tourism marketing context, the destination perception is considered to be a major influential predictor in directing decision-making and consumer behaviors (Woodside and Lysonski, 1989). Destination attributes are commonly used in the empirical research to measure tourists' expectations of a destination (Truong and King, 2009; Chen and Tsai, 2007; Žabka et al,2010). Of such empirical studies, the majority have examined the expectations of particular places, such as countries or cities. Destination attributes are the main factors formulated by researchers for the purpose of describing the various aspects of a country's image, which predominantly influences a person's expectation of that destination. This expectation cannot be easily altered or manipulated by any other aspect of the destination selection process (Beerli and Martin, 2004; Kotler et al, 1993).

Although there are many attributes associated with a destination, the fast growth of cultural tourism has been on the forefront for some researchers, and the cultural attractions have become the most important attribute(Miller, 1997; Smith, 2003; Esu and Arrey, 2009) during the past decade. Due to an increase in the percentage of people who enjoy traveling, the tourism industry has become a massive market and can now be defined as a "landscape industry", which is fully integrated into the destinations' environments (Formica, 2000, Martin, 2005). Tourists' destination choices are often influenced by convenience. Thus, destinations in closer proximity to one's home would be more likely chosen over destinations offering similar products but located at a greater distance (McKercher, 1998; Esu and Arrey, 2009). In addition, Dwyer and Kim (2003) state that local people's attitudes toward tourists are a major social factor in the formation of the macro-environment of a destination, which may influence tourists' satisfaction with their trip and is, therefore, vital to the success of the destination (Andriotis and Vaughan, 2003). Lai and Vinh (2012) note that the services of a destination are the most important factor in tourists' destination choices. Thus, the prosperity of a destination's tourism is highly related to its provision of numerous ancillary services (Dwyer and Kim, 2003). The above analysis clearly indicates that price, culture, entertainment, relaxation, landscape, weather, accessibility, safety, local people's attitudes toward tourists, and service are commonly used as attractive attributes for a destination to attract tourists. However, each destination will be visited for its own unique set of destination attributes.

To execute a successful promotional strategy, it is important to understand the expectations of tourists by analyzing the effects that such expectations have on tourists' destination selections, consumption of goods and services and choosing to revisit (Stevens, 1992,p. 46). It is generally accepted that tourists have expectations after selecting a destination for a holiday and that their satisfaction levels during and after their holiday period are functions of their expectations (Truong and Foster, 2006). Understanding their expectations will give important clues in developing destination attractiveness and improving tourist goods and services. To understand tourists' differences in perceptions, images and motivations toward a destination are essential to understand and predict tourism demand and its impact on the tourism location. Zahra $(2012$, p.20) indicates that "the creation of an image in consumer mind depends on the degree of familiarity obtained from all social and cultural sources and most importantly for destination marketing organizations the ability to understand consumer expectation and offer tourism product accordingly". In fact, this understanding of destination imagery and visitor perception is critical to a destination and provides the basis for more effective and efficient future strategic planning for the destination. In practical terms, this implies that destination image studies are a prerequisite to a successful marketing strategy. A successful promotional strategy necessitates the understanding of when the image of the destination forms and at what point the image influences a consumer's selection choice of a particular destination (Sirakaya, et al, 2004). A major objective of any destination positioning strategy should be to 
reinforce the positive images already held by the target audience, to correct any negative images, andto create a new image (Pike, and Ryan, 2004). On the other hand, destination images influence tourists' decisions and behaviors towards the destination as well as their satisfaction levels and recollections of the experience through the destination loyalty. Therefore, perceived images through promotional activity should be the basis of the evaluation or selection process and, thus, provide the link between motivations and destination selection (O'Leary and Deegan, 2003). After reviewing 142 papers of destination image from 1973 to 2000, Pike (2004) addresses that the brand identity of a destination is the image recognition of a destination, and the brand image refers to how consumers perceive both the brand identity and brand positioning to enhance the resemblance between brand identity and image. However, there are gaps in the literatures as well as lack of examining the links among promotional activities, tourist expectation, tourist satisfaction, and destination loyalty. From the above discussion, this study proposes the following hypotheses:

H1: Promotional activity is positively related to the tourist expectation of the destination.

$\mathrm{H} 2$ : Promotional activity is positively related to the overall satisfaction of the destination.

H3: Promotional activity is positively related to the destination loyalty.

\subsection{The Relationship among Tourist Expectation, Satisfaction and Loyalty}

Teas (1994, p. 134) notes that the "expectation can be defined as the performance of the establishment, ideal performance or desired performance." Oliver (1997) also states that the expectation can be interpreted as prior estimations made by customers while receiving services. To determine the level of customer satisfaction with a specific holiday destination, previous researchers have used various instruments that generate gap scores based on the difference between the expectation and perception of the delivery of particular services associated with that destination (Moutinho, 1987; Parasuraman et al, 1988; Abdeldayem and Khanfer, 2007). This approach is not holistic in that it does not address the total holiday experience. Generally speaking, the expectation can be defined as the ideal or desired performance of the establishment. The most commonly applied framework in service marketing research deems satisfaction as an emotional response that follows from cognitive responses to service experiences (Valle et al, 2006). Satisfaction affects the decisions made when choosing a destination, the consumption of goods and services at the destination, and the intention to revisit the destination. Repeat visitation is important at the broad economic level and for the individual attraction in particular as well (Žabka et al,2010). Barsky and Labagh (1992) introduce the expectancy - disconfirmation paradigm into the field of lodging research. The proposed model in these studies was constructed around the assumption that customer satisfaction was the function of disconfirmation, measured by nine "expectations met" factors that were weighted by the specific important attributes of employee attitude, location, room, price, facilities, reception, service, packing and food and beverage. As a result, customer satisfaction was found to be correlated with a customer's willingness to return (Chen and Tsai, 2007; Žabka et al, 2010; Mohamad et al, 2011).

Oliver (1999, p. 34) defines the loyalty as "a deeply-held predisposition to repatronize a preferred brand or service consistently in the future, thereby causing repetitive same brand purchasing, despite situational influences and marketing efforts having the potential to cause switching behavior". In the context of tourism, Kuusik et al (2011) note that destination loyalty is viewed as a tourist's level of intention to revisit the destination (Kozak, 2001; Jang and Feng, 2007) and also as the tourist's perception of a recommendable place (Chen and Gursoy, 2001). Similarly, Kuenzel and Katsaris (2009) describe post-visit behavior as the intention to return (purchase intention/loyalty) and recommendations through word-of-mouth (WOM). According to Cheng et al. (2011), services are more natural "carriers" for WOM than goods are, as services/products, such as resorts or restaurants, are highly affected by WOM. Therefore, destination loyalty can be described as the behavioral intention of the customers to revisit and disseminate positively through word of mouth favorable recommendations about a particular destination to others. Jacoby and Chestnut (1978) demonstrate three ways of measuring loyalty as: (1) behavioral approach, (2) attitudinal approach and (3) composite approach. Petrick (2002) depicts that satisfaction is an excellent predictor of repurchase intentions, and Barsky (1992) mentions that satisfaction is frequently influenced by the expectation while expectations may assist in the understanding of satisfaction formation. Cole and Illum (2006) find that satisfaction (affective component) mediates the effect of service quality (cognitive component) on behavioral intentions (conative component). Chi and Qu (2008) conclude that attribute satisfaction is antecedent to overall satisfaction and that attribute satisfaction and overall satisfaction are both determinants of loyalty. In addition, Mahadzirah et al(2011) provide empirical evidence that confirmed the positive and significant relationship between tourist satisfaction and destination loyalty. From the findings of previous literature reviews, this study proposesthe following hypotheses:

H4: Tourist expectation is positively related to the overall satisfaction. 
H5: Tourist expectation is positively related to the tourist destination loyalty.

H6: The higher the overall satisfaction is, the more positive the destination loyalty will be.

Figure 1 shows the research framework.

H3

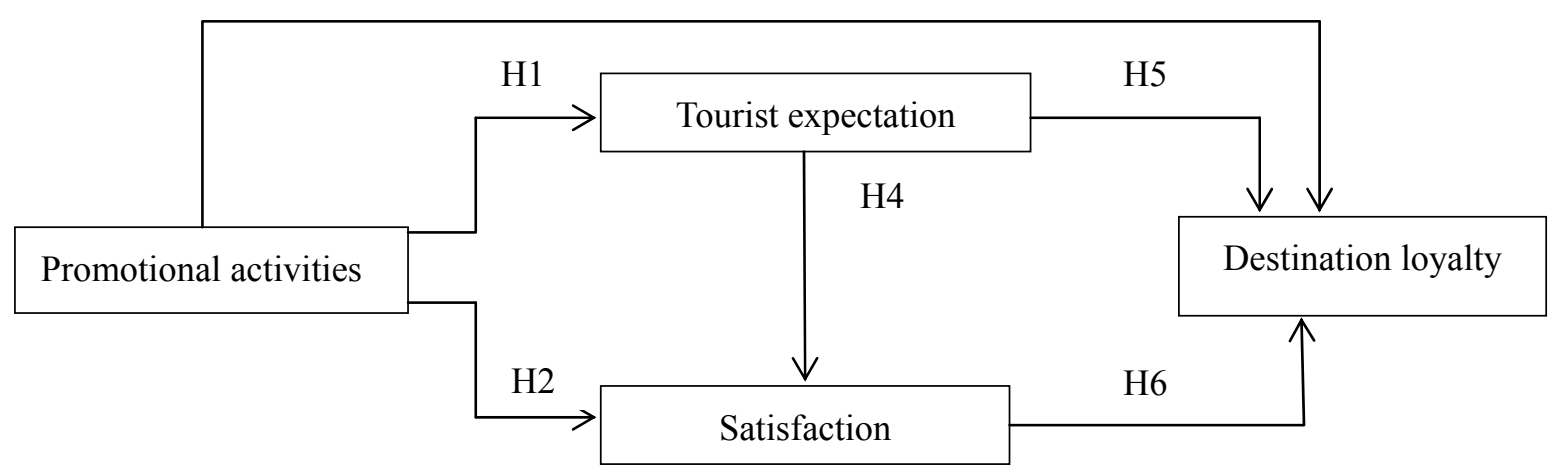

Figure 1. The conceptual model of this study

\section{Research Method}

\subsection{Questionnaire and Sample Design}

The questions in the questionnaire are based on a review of the relevant literature and on interviews conducted with tourists and tourism experts. The experts include three professors in a tourism college, three tourism experts in the tourism industry and twenty tourists in Hanoi. The questionnaire consists of four parts. The first part of the questionnaire addresses promotional activities, with five items derived from the interviews and from a previous study (Lai and Vinh, 2012): information source, online system available, visa application process, tourism agency service and tour program designed. The second part of the questionnaire contains questions regarding tourist expectation and includes the HOLSAT instrument (Tribe and Snaith, 1998; Truong and Foster, 2006, Truong and King, 2009, Lai and Vinh, 2012), with four attributes considered: environmental framework, heritage/cultural festival, staff service and tourism infrastructure. The third part contains questions relating to tourist satisfaction, using three items (pleased that decided to visit the tourist destination, visit the tourist destination exceeded expectations, delighted about this destination) based on the adaptation of the universal scale from Oliver (1997). The fourth part addresses the construction of destination loyalty, which operates on two items ("I would choose the destination again for my future travel" and "I will recommend the destination to friends and relatives") pertaining to loyalty commitment and repurchase (revisit) intentions (Sirakaya et al, 2004; Tian-Cole et al,2002). All of the questions regarding promotional activity, tourist expectation, tourist satisfaction and destination loyalty were measured by five-point Likert scales (ranging from 1=strongly disagree to $5=$ strongly agree). The survey instrument was revised by 3 professors in a tourism college and by 3 experts in the tourism industry and was then pilot tested by 30 graduate students from the tourism program in Hanoi University of Business and Technology, Hanoi, Vietnam (Note 1). The questionnaire also contained a number of questions related to demographic variables.

As the purpose of the study is to identify and analyze tourists' satisfaction after visiting Vietnam, specific tourism sites in Vietnam such as Hanoi, Halong bay, Hue city, or Danang city were not queried. Thus, the Noibai International Airport (Hanoi city in the north) and Tansonnhat International Airport (Hochiminh city in the south) were selected as the interview sites. Since Hanoi is the capital city of Vietnam and was listed $\mathrm{f}$ by Smart Travel as one of Asia's top 10 destinations in 2010, and Hochiminh city is the biggest business city in Vietnam. Our interview samples selecting from the airports of Hanoi and Hochiminh cover most of the tourism destinations in Vietnam. The primary data were finally collected in June and July of 2012 in the boarding areas of the Noibai and Tansonnhat International Airports, where international tourists who were finishing their visits to Vietnam were awaiting their departures. After distributing a total of 400 questionnaires over 4weeks, 257 questionnaires were collected, 32 of which were incomplete. The usable and effective questionnaires for this study totaled 225, 
representing a response rate of $56 \%$, which is valid based on Barrett's (2007) suggestion for the above 200 observations.

\subsection{Measures}

The questionnaire was originally prepared in English. The statistical package for SPSS version 20.0 and the structural equation modeling tool AMOS 20 were used to analyze the data for the questionnaires. First, an explorative factor analysis (EFA) using the principle component method was performed to reduce the number of variables and to look for underlying constructs within the data. Data were checked for suitability for this type of analysis. This study calculated the determinant of the correlation matrix to eliminate the extreme correlations between different variables, and then followed with the assumption that a factor analysis for those correlations among variables would be moderate. Second, based on the questionnaire, an appropriate assessment for confirmatory factor analysis (CFA) was used to assess the validity and reliability of the constructs of the measurement scales (Hair et al, 2006). Finally, a series of steps using SEM analysis was utilized to test the moderating significance of the hypotheses. The hypothesized relationships depicted in Figure 1 were measured using AMOS 20.0 through path analysis. All of the hypotheses in this study were developed based on empirical evidence from previous studies.

\section{Results Analysis}

\subsection{Respondent Profile}

The usable questionnaires were almost evenly distributed across gender lines among the 225 respondents at $54.7 \%$ male and $45.3 \%$ female. A plurality of the visitors fell into the $35-44$ years old age group, representing $35.1 \%$ of the respondents. Respondents younger than 24 years of age were few, accounting for only $9.3 \%$. Most of the tourists were first-time Vietnam visitors (75.6\%). In addition, the survey revealed that the education level of tourists traveling to Vietnam was relatively high, with $40.4 \%$ having earned at least a bachelor's degree. Only $4.4 \%$ of respondents had no higher than a grade-school education. With regard to their purpose for visiting Vietnam, the survey revealed that $71.1 \%$ of the visitors reported as destination-unrestricted and $28.9 \%$ indicated as destination-restricted. Regarding tourist nationality, $24.4 \%$ were visiting from China, $24.9 \%$ were visiting from the United States and $16.7 \%$ were visiting from Europe, Just $10.2 \%$ of the visitors were Japanese, and the remaining $24.4 \%$ were visiting from other countries. Table 1 shows the respondent profile.

Table 1. Respondent profile

\begin{tabular}{lll}
\hline Demographic characteristic & Frequency (total 225) & Percentage (\%) \\
\hline Gender & 123 & 54.7 \\
Male & 102 & 45.3 \\
Female & & \\
Age & 21 & 9.3 \\
16-24 & 46 & 20.4 \\
$25-34$ & 79 & 35.1 \\
$35-44$ & 44 & 19.6 \\
45-54 & 35 & 15.6 \\
55- over & & \\
Education level & 10 & 4.4 \\
Grade school & 67 & 29.8 \\
High school & 91 & 40.4 \\
Lower university degree & 57 & 25.3 \\
University degree and higher & & 75.6 \\
Past experience & 170 & 24.4 \\
First-timers & 55 & 71.1 \\
Repeaters & & 28.9 \\
Purpose & 160 & 16.0 \\
Destination-unrestricted & 65 & 24.9 \\
Destination-restricted & & 24.4 \\
Nationality & 36 & 10.2 \\
Europe & 56 & 24.4 \\
USA & 55 & \\
China & 23 & \\
Japan & 55 & \\
Other & &
\end{tabular}




\subsection{Reliability Analysis}

In this study, the principle component method is used for the explorative factor analysis. Four factors with 14 items are loaded into the system, and the result indicates that $76 \%$ of the variance of the four factors has been explained with an eigenvalue that is greater than 1.0. Three items of the loading factor are less than 0.5 , which are deleted from the scale. The varimax-rotated factorial pattern implies that the first factor concerns promotion activity ( 5 items, Cronbach's $\alpha=0.918$ ); the second factor relates to tourist expectation (4 items, Cronbach's $\alpha=0.808$ ); the third factor consists of the characteristics of tourist satisfaction ( 3 items, Cronbach's $\alpha=0.714$ ); and the fourth factor relates to destination loyalty ( 2 items, Cronbach's $\alpha=0.770$ ). The arithmetic means of the 4 multi-item factors were used to build the construct. The result of the factor analysis is shown in Table 2. From the results, the Cronbach's $\alpha$ coefficients ranged from 0.918 to 0.714 . Therefore, all of the factors were accepted and deemed reliable, as recommended by Nunnally (1978).

\subsection{Construct Validity}

Validity convergence was used to assess the validity of the instruments used in this study. According to the study of Hair et al (2006), construct validity is crucial to ensure that a set of items actually represents the theoretical latent construct. In addition to the standardized factor loadings in the CFA, the validity convergence in this study was examined by observing the value of composite or construct reliability (CR) and variance extracted (VE) for each of the dimensions of all of the factors. As noted by Hair et al (2006), the CR values should be greater than 0.6 , while VE should be above 0.5. The CR, VE, and standardized factor loadings are the indicators for the validity convergence. The rule of thumb for good reliability estimation is 0.7 or higher, which means that all observed variables consistently represent the same latent construct. As shown in Table 3, t-values for all of the standardized factor loadings of the items were found to be significant $(p<0.01)$. In addition, construct reliability estimates ranging from 0.772 to 0.921 exceeded the critical value of 0.6 recommended by Hair et al (2006). The average variances extracted (AVE) for all of the constructs fell between 0.510 and 0.692 and were greater than the value of 0.5 suggested by Hair et al (2006). Finally, the discriminant validity was found to be evident in the AVE because the constructs were greater than the squared correlation between the constructs, and hence the relationships between measures and constructs were stronger than the relationships between constructs themselves (Murphy et al, 2000). This result indicates that all of the items have an acceptable convergent validity and discriminant validity in explaining the theorized constructs (Hair et al, 2006).

Table 2. Factor analysis

\begin{tabular}{|c|c|c|c|c|c|c|}
\hline Factor /item & $\begin{array}{l}\text { Factor } \\
\text { loading }\end{array}$ & Mean & $\mathrm{SD}^{*}$ & $\begin{array}{l}\text { Variance } \\
\text { explained (\%) }\end{array}$ & $\begin{array}{l}\text { Cumulative } \\
\text { variance } \\
\text { explained (\%) }\end{array}$ & Cronbach's $\alpha$ \\
\hline$\overline{\text { Promotion activities (PA) }}$ & & & & 28.388 & 28.388 & .918 \\
\hline Information source & .878 & 3.07 & .933 & & & \\
\hline Online system available & .861 & 3.15 & .894 & & & \\
\hline Visa application process & .840 & 3.19 & .950 & & & \\
\hline Tourism agency service & .818 & 3.05 & .924 & & & \\
\hline Tour program designed & .758 & 3.13 & .989 & & & \\
\hline Tourist expectation (TE) & & & & 22.995 & 51.383 & .880 \\
\hline Environmental Framework & .837 & 3.27 & .901 & & & \\
\hline Heritage/Cultural Festival & .832 & 3.51 & .847 & & & \\
\hline Staff Service & .767 & 3.07 & .959 & & & \\
\hline Tourism Infrastructure & .728 & 3.16 & .890 & & & \\
\hline Tourist satisfaction (TS) & & & & 14.436 & 65.819 & .714 \\
\hline $\begin{array}{l}\text { Pleased that decided to visit the } \\
\text { tourist destination }\end{array}$ & .750 & 2.10 & .927 & & & \\
\hline $\begin{array}{l}\text { Visit the tourist destination } \\
\text { exceeded expectations }\end{array}$ & .750 & 3.04 & .801 & & & \\
\hline $\begin{array}{l}\text { Delighted about this destination } \\
\text { Destination loyalty (DL) }\end{array}$ & .639 & 2.98 & .899 & 10.480 & 76299 & .770 \\
\hline $\begin{array}{l}\text { I would choose the destination } \\
\text { again for my future travel }\end{array}$ & .799 & 3.00 & .968 & & 10.299 & .170 \\
\hline $\begin{array}{l}\text { I will recommend the destination } \\
\text { to friends and relatives }\end{array}$ & .594 & 2.98 & .982 & & & \\
\hline
\end{tabular}

* Std. Deviation 
Table 3. Constructs validity

\begin{tabular}{llllllll}
\hline Constructs & Estimate & S.E. & $\begin{array}{l}\text { Standardized } \\
\text { factor loading }\end{array}$ & T-value & P-value & C.R. & A.V.E. \\
\hline PA1 & 1.000 & & .934 & & & .921 & .692 \\
PA2 & .899 & .043 & .877 & 20.775 & $0.0^{* * *}$ & & \\
PA3 & .859 & .053 & .788 & 16.313 & $0.0^{* * *}$ & & \\
PA4 & .888 & .048 & .837 & 18.599 & $0.0^{* * *}$ & & \\
PA5 & .838 & .058 & .738 & 14.426 & $0.0^{* * *}$ & & \\
TE1 & 1.000 & & .842 & & & .880 & .654 \\
TE2 & .774 & .068 & .693 & 11.428 & $0.0^{* * *}$ & & \\
TE3 & 1.099 & .070 & .869 & 15.724 & $0.0^{* * *}$ & & \\
TE4 & .951 & .067 & .811 & 14.251 & $0.0^{* * *}$ & & \\
TST1 & 1.000 & & .475 & & & .744 & .510 \\
TST2 & 1.163 & .184 & .640 & 6.333 & $0.0^{* * *}$ & & \\
TS3 & 1.874 & .271 & .919 & 6.916 & $0.0^{* * *}$ & & \\
DL1 & 1.000 & & .690 & & & .772 & .646 \\
DL2 & 1.333 & .132 & .906 & 10.071 & $0.0^{* * *}$ & & \\
\hline C & 1.30 & & & &
\end{tabular}

C.R. Construct reliability, ${ }^{* * *} \mathrm{P}<0.01$

\subsection{Structure Model Fit and Model Coefficients}

The measurement model was observed for overall fitness by referring to other fit indices, as suggested by Byrne (2001), Kline (2005), Schumacker and Lomax (2004), and Tabachnick and Fidell (2007). The fit indices reported in this study include the Root Mean Square Error of Approximation (RMSEA) for model fit and the Tucker-Lewis Index (TLI) and the Comparative Fit Index (CFI) for model comparisons, which indicate that the model is adequately fit and that the cutoff values are 0.90 or higher for CFI and TLI (Byrne, 2001; Kline, 2005; Schumacker and Lomax 2004), 0.08 or lower for RMSEA, and 0.5 or higher for the Parsimony-Adjusted Measures of CFI (PCFI) (Byrne 2001; Kline,2005; Schumacker and Lomax, 2005) and others listed in Table 4. The acceptable range for normed chi-square was 1 to 5 (Schumacker and Lomax, 2005) and $\mathrm{P}<0.05$ or PClose $>0.5$.

A CFA of the constructs of promotional activity, tourist expectation, tourist satisfaction and destination loyalty were also performed in this study. The final model contained five reflective indicators for promotional activity, four for tourist expectation, three for tourist satisfaction and two for destination loyalty. Employing the covariance matrix among the 14 measurement items as the inputs, an SEM analysis was conducted to examine the relationships between each pair of constructs as hypothesized. The results of the SEM analysis are shown in Table 5. The fit indices of the model are summarized in Table 4. The overall model indicates that $x^{2}$ is 130 with 71 degrees of freedom (d.f.) $(\mathrm{p}=0.000)$. Technically, the $\mathrm{p}$-value should be greater than 0.05 , which is statistically insignificant. However, in practice the $x^{2}$-value is very sensitive to sample size and frequently results in the rejection of a well-fitting model. Hence, the ratio of $x^{2}$ over d.f. has been recommended as a better fit than $x^{2}$ itself (Hair et al, 2006). A common level of the $x^{2} /$ d.f. ratio is below 5 (though below 3 is considered to be better). The $x^{2} /$ d.f. ratio of the model is 1.83 (i.e., 130/71) and (Pclose $>0.5$ ), thereby indicating an acceptable fit. Furthermore, $\mathrm{CFI}=0.97$ and $\mathrm{TLI}=0.955$ (both important indices) are higher than 0.95 , and RMSEA is $0.06<0.08$ indicating a good model fit. The other indices (NFI=94 and RFI=.906 $>0.9$, $\mathrm{PCFI}=0.656$ and $\mathrm{PNFI}=0.633>0.5$ ) are all within acceptable ranges. 
Table 4. Goodness of fit indices of model

\begin{tabular}{lll}
\hline & Criteria & Indicator \\
\hline$x^{2}$ - test & & \\
$x^{2} /$ d.f. & $<2$ & $1.831(130.024 / 71)$ \\
Pcolse & $>0.5$ & 1.35 \\
Fit indices & & \\
CFI & $>0.95$ & 0.970 \\
NFI & $>0.90$ & 0.940 \\
TLI & $>0.95$ & 0.955 \\
RFI & $>0.90$ & 0.906 \\
RMSEA & $<0.08$ & 0.061 \\
PCFI & $>0.50$ & 0.656 \\
PNFI & $>0.50$ & 0.633 \\
\hline
\end{tabular}

\subsection{Structural Model Analysis}

The result in Table 2 indicates that most of the mean scores of the five methods of promotional activities in terms of tourist satisfaction are higher than 3.0, which is the value of the moderate satisfied level. Thus, it cannot be concluded that the five methods satisfied the international tourist in choosing Vietnam as their destination. In addition, the mean scores of information source and tourism agency just equal to 3.07 and 3.05. On the other hand, online system available $(M=3.15)$, visa application process $(M=3.19)$ and tour program designed $(M=3.13)$ are ranked higher in making visitors satisfaction. It shows the need for applying the concept of interactive marketing and improving the information system.

Regarding the expectations of Vietnam tourist attributes, international tourists seem not to be satisfied with service providers (Mean=2.10, 3.04 and 2.98, see Table 2). As a result, the rate of intent to return (destination loyalty) is negatively affected (Mean=3.0 and 2.98, see Table 2). However, it is evident that travelers are highly motivated to learn about the history and culture of Vietnam (Mean=3.56). In addition, nature is also considered as a site attraction for Vietnam (Mean=3.27) while service staff and infrastructure are comparatively lower (Mean=3.07 and 3.17, see Table 2).

All hypothetical relationships in our conceptual model are supported (see Table 5). The promotional activity is positively related to the tourist expectation of the destination $(\mathrm{H} 1: \beta=0.309, \mathrm{t}=5.717, \mathrm{p}<.0 .01)$. It means that promotional activity is highly recommended for purchase decisions after the destination selection, such as choosing accommodation, transportation and activities. Understanding the perceptions of tourist on the destination is useful in planning promotional and marketing activities of Vietnam as destination's tourism products. The results of estimations for the relationships of the promotional activity and visitor satisfaction are strongly consistent with the proposed hypothesis $(\mathrm{H} 2: \beta=0.212, t=4.924, p<0.01)$. In this perspective, the visitor satisfaction is influenced from the demand and supply sides. The effect of promotional activity on destination loyalty is also strong $(\mathrm{H} 3: \beta=0.367, \mathrm{t}=6.228, \mathrm{p}<0.01)$. Vietnam marketers expect to realize the visitor's dreams to experience quality service with a high quality based experience. In order to realize this ambition, any experience should include all the elements that attract visitors such as "The Five A's": attractions, activities, accessibility, accommodations and amenities (Truong and King, 2009) or environmental framework, heritage/cultural festival, staff service and tourism infrastructure (Lai and Vinh, 2012). When these elements are appropriately used, they will meet the visitor's demand and more likely to result in satisfaction and destination loyalty. Similarly, the prediction that tourism expectation is positively related to the overall satisfaction is supported $(\mathrm{H} 4: \beta=0.246, \mathrm{t}=5.339, \mathrm{p}<0.01)$. Hypothesis 5tested the relationship of tourism expectation and destination loyalty is strongly supported (H5: $\beta=0.362, \mathrm{t}=6.395, \mathrm{p}<0.01)$. The finding in $\mathrm{H} 4$ and H5 supports the need for destination marketers creating positive images of the destinations and improving the quality of tourism product. A visitor is satisfied when the quality of the facilities and services meets or exceeds expectations, and thus it leads to behavioral intentions to visit Vietnam. Finally, the testing of the relationship between tourist satisfaction and destination loyalty (the higher the overall satisfaction, the more positive the destination loyalty is) has been verified and is supported (H6: $\beta=0.192, t=4.773, p<0.01$ ). 
Table 5. Result of hypothesis testing

\begin{tabular}{|c|c|c|c|c|c|c|c|c|}
\hline \multicolumn{4}{|c|}{ Path } & \multirow{2}{*}{$\begin{array}{l}\text { Estimate } \\
.309\end{array}$} & \multirow{2}{*}{$\begin{array}{l}\text { S.E. } \\
.054\end{array}$} & \multirow{2}{*}{$\begin{array}{l}\text { T-value } \\
5.717\end{array}$} & \multirow{2}{*}{$\begin{array}{l}\text { P-value } \\
0.00^{* * *}\end{array}$} & \multirow{2}{*}{$\begin{array}{l}\text { Hypothesis result } \\
\text { supported }\end{array}$} \\
\hline H1 & PA & $-->$ & $\mathrm{TE}$ & & & & & \\
\hline $\mathrm{H} 2$ & PA & $-->$ & TS & .212 & .043 & 4.924 & $0.00^{* * *}$ & supported \\
\hline $\mathrm{H} 3$ & PA & $-->$ & DL & .367 & .059 & 6.228 & $0.00^{* * *}$ & supported \\
\hline $\mathrm{H} 4$ & $\mathrm{TE}$ & $-->$ & TS & .246 & .046 & 5.339 & $0.00 * * *$ & supported \\
\hline H5 & $\mathrm{TE}$ & $-->$ & DL & .361 & .056 & 6.395 & $0.00^{* * *}$ & supported \\
\hline H6 & TS & $-->$ & DL & .192 & .040 & 4.773 & $0.00^{* * *}$ & supported \\
\hline
\end{tabular}

\section{Discussion and Conclusion}

\subsection{Discussion}

This study provides a framework for understanding the interrelationships between promotional activity, tourist expectation, tourist satisfaction and destination loyalty. By using the SEM method, this study adds empirical support to the literature and has tested six hypotheses related to the promotional activities and evaluative factors affecting the destination loyalty of visitors in Vietnam. According to the results in this study, the six hypotheses are supported. Regarding hypothesis 1 , the result indicates that promotional activity is positively related to the TE of the destination. This finding corroborates the findings in Baloglu's (2001) study in that the information sources through which tourism promotional activity is executed should include formal interpersonal sources, external formal sources, commercial sources, and professional sources. Information is the channel through which factual knowledge regarding a destination's attributes can be provided and can influence the tourist expectation of a destination. However, in Baloglu's study, the results reveal four distinct loyalty levels: high loyalty, latent loyalty, and low loyalty, which was divided into two distinct sub-levels (natural switchers and experiential switchers), whereas the spurious loyalty group was not supported. The findings are also consistent with the results of other studies in the area of tourism (Yüksel and Akgül, 2007) in that the relationships of promotional activity and tourist satisfaction and the effect of promotional activity on destination loyalty are strongly consistent with the proposed hypotheses. Similar to the findings of this study, Teas (1994) and Aksu et al (2010) indicate that expectations of a destination affect satisfaction levels and destination loyalty. The final hypothesis of this study, which states that the higher the overall satisfaction, the more positive the DL is, has been validated and supported. This result is consistent with those of Chen and Tsai (2007) and Žabka et al. (2010), which both provide empirical evidence confirming a positive and significant relationship between tourist satisfaction and destination loyalty. However, in their studies, the perceived quality is considered as the mediating variable for tourist satisfaction and destination loyalty. In Chen's and Tsai's study, the destination image and trip quality adopt similar variables (the path coefficient between the destination image and the trip quality equaled0.91) to assume that the similarity of both constructs affects the estimation results. Žabka et al. (2010) indicate that the perceived quality of a destination's offerings as a formative construct does not permit the generalization of the relevant indicators across different destinations. Therefore, the relationship of promotional activity, tourist expectation, tourist satisfaction and destination loyalty in this study may provide a more specific approach to the core of the study, and the concept and degree of customer loyalty as two critical indicators can measure the success of a product-marketing strategy applied in the tourism industry (Mohamad et al, 2011).

The globalization of travel and improved accessibility of tourist destinations are increasing competitive pressures for destination managers (Žabka et al, 2010). The results have identified several key benefits sought by respondents that will be useful for promoting the Vietnamese tourism industry. As noted by Truong (2006), Vietnam is perceived as an attractive tourism destination in terms of its scenic beauty, history and culture, the friendliness of the local people, food, and cultural and natural attractions as well as being perceived as an economical vacation destination. This perspective requires new and more efficient promotional activities. According to the results of this study, the marketing planners can use the following five methods of promotion: giving a clear and specific information source, making an online system available, ensuring a flexible visa application process, employing professional tourism agency services and well-designed tour programs. In contrast to the high expectations of Vietnam as a destination, tourists seem not to be satisfied with the services given in Vietnam (Mean=2.10, 3.04 and 2.98, see Table 2). As a result, the rate of intent to return (destination 
loyalty) is considered low (Mean=3.0 and 2.98, see Table 2). This is consistent with the result of Truong's (2005) and Truong's and King's (2009) studies, which adopt the HOLSAT model and compare the satisfaction and dissatisfactions without explaining the link between promotional activity and tourist expectation. However, travelers are interested in learning more about the history and culture of Vietnam (Mean=3.56). Nature is also considered as a site attraction for Vietnam (Mean=3.27) while service staff and infrastructure are comparatively lower (Mean=3.07 and 3.17, see Table 2). This result is similar to Lai's and Vinh's (2012) suggestion that improving the link between a destination's attributes and promotional activity is highly recommended to satisfy visitors and to improve the destination's image. In addition, a destination's image can significantly impact tourists' levels destination loyalty. Tourists who enjoy better services than they had initially expectedare more likely to return to the destination in the future.It is vital for Vietnamesetourism managers and marketers to gain a competitive advantage over regional or international competitors by improving customer impressions to develop a solid destination branding image.

\subsection{Academic Contributions}

Existing models focus on tourist satisfaction and destination loyalty by examining the influence of overall travel satisfaction on destination loyalty (Ahmad Puad et al, 2011; Chi and Qu, 2008; Chen and Tsai, 2007; Mahadzirah et al, 2011). However, there is a dearth of studies that attempt to examine the links among promotional activities, tourist expectation, and tourist satisfaction and destination loyalty. Applying SEM method, this study contributes to the academic knowledge by examining tourism theory in the context of Vietnam. This study also improves previous research model in tourism marketing (Yüksel and Akgül, 2007, Chen and Tsai 2007, Žabka et al., 2010, and Mohamad et al., 2011) by adding the important factors of promotional activities and tourist expectation. Our model gives a more extended and integrated vision of the effects of promotional activity and tourist expectation on tourist satisfaction and destination loyalty was proposed and tested in all phases of tourist decision-making. On the other hand, by testing the relationship of promotional actives and tourist expectation, the result shows the need for applying the interactive marketing concept in promoting Vietnam tourism industry. The findings of this study are important since Vietnam has been gaining higher popularity as an appealing tourism destination (Bui, 2011) but there are still limited researches on Vietnam tourism.

\subsection{Managerial Implications}

The findings of this study can help tourism marketers associate with the destination marketing efforts and promotional activities and be successful destination management organizations. Promotional activities are important factors for reducing the uncertainty about tourists' destinations by creating and fulfilling tourists' expectations. When marketers understand how consumers search for information, they can create more effective campaigns to influence consumers' expectations (McColl and Fetter, 1999). Our findings could help tourism marketers of tour operator and travel services to better understand the structure of destination image and to identify the related core attributes of destination. In addition, the promotional activities can be implemented based on tourism attractions such as natural and cultural attractions.

This study recommends that the service quality should be improved, including the tourism product and service staffs, to attain a higher overall satisfaction level and improve the overall destination image as well as the destination loyalty from tourists. Accordingly, with not only these tourism attributes but also with well-prepared marketing plans as well as promotional activities, the best strategies for enhancing destination competitiveness may be established for the tourism destinations. In addition, tourism-industry trends reveal the necessity of acquiring advanced technology and information systems to improve the promotion activities of the tourism industry. In this context, tourist organizations should use Internet as a promotional activity for purchase decisions after the destination selection, such as choosing accommodation, transportation and activities. Furthermore, understanding tourists' perceptions of the destination is useful in planning promotional and marketing activities of Vietnam as destination's tourism products.

This study shows that visitor experience is influenced by the demand and supply sides. The demand side is formed by the visitor's expectations; therefore, promotional activities have accumulated the facts and useful information about Vietnam in order to help visitor select the right place, service and trip planning. This study suggests that marketing planners can use the following five methods of promotion: providing a clear and specific information source, making an online system available, ensuring a flexible visa application process, hiring qualified professional tourism agency services and selecting well-designed tour programs. When these methods are used and meet the visitor's demand, they are more likely to result in satisfaction and destination loyalty. 


\subsection{Research Limitations}

Although this study contributes to the theoretical and managerial implications, the model used in this study should be more developed in regard to trip quality and perceived value in the future. Namely, another construct could be introduced and tested as it may have a strong impact on promotional activities and expectations. Also, future studies with larger samples could be conducted to allow for comparisons between national and foreign tourist behaviors as well as between experienced and non-experienced tourists.

\subsection{Conclusions}

Since the SEM method in tourism literature is still quite limited (Assaker et al, 2010), this study not only contributes to the managerial implications but also to the theoretical development. This study adds empirical support to the literature while testing six hypotheses related to the promotional activities and evaluative factors affecting the destination loyalty of visitors in Vietnam. According to the results in this study, these results have identified several key benefits that will be useful for promoting the Vietnamese tourism industry. Furthermore, the results also suggest that improving the link between a destination's attributes and promotional activities is highly recommended to satisfy visitor's expectations and to improve the destination's image. This study recommends that the service quality should be improved, including the tourism product and service staffs, in order to attain a higher overall satisfaction level and improve the overall destination image as well as the destination loyalty from tourists. In regard to interactive marketing, the results show that Internet, as a complete and powerful information sources (Brettel and Andrea, 2010), has a positive impact on destination expectations and allows consumers to collect a large variety of information about destinations.

\section{References}

Abdeldayem, M. M., \& Khanfar, M. R. (2007). Consumer Expectation and ConsumeSatisfaction Measurements: A Case Study from India. The Business Review, 8(2), 303-309.

Ahmad Puad, M. S., Seyed Fatemeh, M. S., Azizan, M., \& Jamil, J. (2011). A critical analysis of tourist satisfaction and destination loyalty. Journal of Global Management, 2(1), 178-183.

Aksu, A., İçigen, E. T., \& Ehtiyar, R. (2010). A Comparison of Tourist Expectations and Satisfaction: A Case Study from Antalya Region of Turke. TURIZAM, 14(2), 66-77.

Andriotis, K., \& Vaughan, R. D. (2003). Urban Residents' Attitudes toward Tourism Development: The Case of Crete. Journal of Travel Research, 42(4), 172-185. http://dx.doi.org/10.1177/0047287503257488

Assaker, G., Vinzi, V. E., \& O'Connor, P. (2010). Structural Equation Modeling in Tourism Demand Forecasting: A Critical Review. Journal of Travel and Tourism Research, (Spring/Fall), 1-27.

Baloglu, S., \& Mangaloglu, M. (2001). Tourism destination images of Turkey, Egypt, Greece and Italy as perceived by US-based tour operators and travel agents. Tourism Management, 22, 1-9. http://dx.doi.org/10.1016/S0261-5177(00)00030-3

Baloglu, S. (2001). An Investigation of a Loyalty Typology and the Multidestination Loyalty of International Travelers. Tourism Analysis, 6(1), 41-52.

Barrett, P. (2007). Structural equation modelling: Adjudging model fit. Personality and Individual Differences, 42, 815-824.

Barsky, J. D. (1992). Customer satisfaction in the hotel industry: Meaning and measurement. Hospitality Research Journal, 16(1), 51-73.

Barsky, J. D., \& Labagh, R. (1992). A Strategy for Customer Satisfaction. Cornell Hotel and Restaurant Administration Quarterly, 33(5), 32-40.

Beerli, A., \& Martin, J. D. (2004). Factors influencing destination Image. Annals of Tourism Research, 31(3), 657-681.

Brettel, M., \& Spilker-Attig, A. (2010). Online advertising effectiveness: a cross-cultural comparison. Journal of research in interactive marketing, 4(3), 176-196. http://dx.doi.org/10.1108/17505931011070569

Buhalis, D. (1998). Strategic use of information technologies in the tourism industry. Tourism Management, 9 , 409-421. http://dx.doi.org/10.1016/S0261-5177(98)00038-7

Bui, H. (2011). Congruency between the projected and perceived tourism destination image of Vietnam. Journal of International Business Research, 10(2), 1-13.

Byrne, B. M. (2001). Structural equation modeling with AMOS, Lawrence Erlbaum Associates, Mahwah. 
Chen, C. F., \& Tsai, D. (2007). How destination image and evaluative factors affect behavioral intentions? Tourism Management, 28, 1115-1122. http://dx.doi.org/10.1016/j.tourman.2006.07.007

Chen, J. S., \& Gursoy, D. (2001). An investigation of tourist's destination loyalty and preferences. International Journal of Contemporary Hospitality Management, 13(2), 79-85.

Cheng-His, F., Tom, M. Y., Lin, F., \& Yu, H. L. (2011). Product type and word of mouth: a dyadic perspective. Journal of Research in Interactive Marketing, 5(2), 189-202.

Chi, C. G., \& Qu, H. (2008). Examining the structural relationships of destination image, tourist satisfaction and destination loyalty: An integrated approach. Tourism Management, 29(4), 624-636. http://dx.doi.org/10.1016/j.tourman.2007.06.007

Cho, B. H. (1998). Assessing Tourist Satisfaction: an Exploratory Study of Korean Youth Tourists in Australia. Tourism Recreation Research, 23(1), 47-54.

Cole, S. T., \& Illum, S. F. (2006). Examining the mediating role of festival visitors' satisfaction in the relationship between service quality and behavioral intentions. Journal of Vacation Marketing, 12(2), $160-173$.

Dann, G. M. S. (1977). Anomie, Ego-Enhancement and Tourism. Annals of Tourism Research, 4(4), 184-94. http://dx.doi.org/10.1016/0160-7383(77)90037-8

Dann, G. M. S. (1981). Tourist Motivation: An Appraisal. Annals of Tourism Research, 8(2), 187-219. http://dx.doi.org/10.1016/0160-7383(81)90082-7

Dwyer, L., \& Kim, C. (2003). Destination Competitiveness. Determinants and Indicators. Current Issues in Tourism, 6(5), 369-414. http://dx.doi.org/10.1016/10.1080/13683500308667962

Esu, B. B., \& Arrey, V. M. E. (2009). Tourists' Satisfaction with Cultural Tourism Festival: a Case Study of Calabar Carnival Festival, Nigeria. International Journal of Business and Management, 4(3), 116-125.

Formica, S. (2000). Destination Attractiveness as a Function of Supply and Demand Interaction. Retrieved from http://www.scholar.lib.vt.edu/theses/available/etd-11142000-15560052

Gomezlj, D., \& Mihalic, T. (2008). Destination Competitiveness-applying different models: The case of Slovenia. Tourism Management, 29(2), 294-307. http://dx.doi.org/10.1016/j.tourman.2007.03.009

Govers, R., Go, F. M., \& Kumar, K. (2007). Promoting Tourism Destination Image. Journal of Travel Research, 46(1), 15-23. http://dx.doi.org/10.1177/0047287507302374

Gunn, C. (1997). Vacationscape - Developing Tourist Areas (2nd ed.). Washington: Taylor \& Francis.

Gursoy, D., \& McCleary, K. W. (2004). An Integrative Model of Tourists' Information Search Behavior. Annals of Tourism Research, 31(2), 353-373. http://dx.doi.org/10.1016/j.annals.2003.12.004

Hair, J. F., Black, W. C., Babin, B. J., Anderson, R. E., \& Tatham, R. L. (2006). Multivariate data analysis (6th ed.). Pearson Prentice Hall, Uppersaddle River.

Hu, Y., \& Ritchie, J. R. B. (1993). Measuring Destination Attractiveness: A Contextual Approach. Journal of Travel Research, 32, 25-34. http://dx.doi.org/10.1177/004728759303200204

Inkeep, E. (1991). Tourism planning: An integrated and sustainable development approach. Van Nostrand Reinhold, New York.

Jacoby, J., \& Chestnut, R. W. (1978). Brand loyalty: measurement and management. New York: John Wiley.

Jang, S., \& Feng, R. (2007). Temporal destination revisit intention: The effects of novelty seeking and satisfaction. Tourism Management, 28(2), 580-590. http://dx.doi.org 10.1016/j.tourman.2006.04.024

Klenosky, D. B. (2002). The "Pull" of Tourism Destinations: A Means-End Investigation. Journal of travel Research, 40(2), 385-395. http://dx.doi.org/10.1177/004728750204000405

Kline, R. B. (2005). Principles and practice of structural equation modeling (2nd ed.). The Guilford Press, New York.

Korzay, M., \& Alvarez, M. D. (2005). Satisfaction and Dissatisfaction of Japanese Tourists in Turkey, Anatolia. An International Journal of Tourism and Hospitality Research, 16(2), 176-193.

Kotler, P., Haider, D. H., \& Rein, I. (1993). Marketing places: Attracting investment, industry and tourism to cities, states and nations. Journal of Consumer Research, 14, 495-508. 
Kozak, M. (2001). Comparative assessment of tourist satisfaction with destinations across two nationalities. Tourism Management, 22(4), 391-401. http://dx.doi.org/10.1016/S0261-5177(00)00064-9

Kuenzel, S., \& Katsaris, N. (2009). A critical analysis of service recovery processes in the hotel industry. TMC Academic Journal, 4(1), 14-24.

Kuusik, A., Tiru, M., Ahas, R., \& Varblane, U. (2011). Innovation in destination marketing: The use of passive mobile positioning for the segmentation of repeat visitors in Estonia. Baltic Journal of Management, 6(3), 378-399.

Lai, W. H., \& Vinh, N. Q. (2012). A Study of Analyzing the Selection of Promotion Activities and Destination Attributes in Tourism Industry in Vietnam - From the Perspective of Tourism Industrial Service Network (TISN). International Journal of Social and Human Sciences, 6, 330-336.

Lew, A. A. (1987). A model of tourist attraction research. Annals of Tourism Research, 14, 553-575.

Lewis, P. G., \& Meadows, A. J. (1995). Canadian tourist information and the UK: plans and perceptions. Tourism Management, 16(1), 67-72. http://dx.doi.org/10.1016/0261-5177(94)00009-Y

Mahadzirah, M., Abdul Manan, A., \& Nur Izzati, A. G. (2011). A structural model of destination image, tourists' satisfaction and destination loyalty. International Journal of Business and Management Studies, 3(2), 167-177.

Martin, M. B. G. (2005). Weather, Climate and Tourism - A Geographical Perspective. Annals of Tourism Research, 32(3), 571-591. http://dx.doi.org/10.1016/j.annals.2004.08.004

McColl-Kennedy, J. R., \& Fetter Jr, R. E. (1999). Dimensions of consumer search behavior in services. The Journal of Services Marketing, 13(3), 242-265.

McKercher, B. (1998). The effect of market access on destination choice. Journal of Travel Research, 37(3), 39-47. http://dx.doi.org/10.1177/004728759803700105

Miller, J. (1997). Cultural Tourism Worthy of Note. Journal of Hotel \& Motel Management, 212(15), 7-17.

Mohamad, M., Abdullah, A. R., \& Mokhlis, S. (2011). Examining the Influence of Service Recovery Satisfaction on Destination Loyalty: A Structural Equation Modeling. Journal of Sustainable Development, 4(6), 3-11.

Molina, A., Gómez, M., \& Consuegra, D. M. (2010). Tourism marketing information and destination image management, African. Journal of Business Management, 4(5), 722-728.

Moutinho, L. (1987). Consumer Behavior in Tourism. European Journal of Marketing, 21(10), 1-44.

Murphy, P., Mark, P., \& Smith, P. B. (2000). The destination product and its impact on traveler perceptions. Tourism Management, 21, 43- 52. http://dx.doi.org/10.1016/S0261-5177(99)00080-1

New Economics Foundation (NEF). (2009). Happy Planet Index. Retrieved from http://english.vov.vn/Home/Vietnam-enters-Top-5-of-2009-Happy-Planet-Index/20097/105677.vov

Nunnally, J. C. (1978). Psychometric theory. McGraw-Hill, New York.

O'Leary, S., \& Deegan, J. (2003). People, pace, place: Qualitative and quantitative images of Ireland as a tourism destination in France. Journal of vacation marketing, 9(3), 213-226. http://dx.doi.org/10.1177/135676670300900302

Oliver, R. L. (1999). Whence consumer loyalty. Journal of Marketing, 63, 33-44.

Oliver, R. L. (1997). Satisfaction: A Behavioral Perspective on the Consumer. Singapore: McGraw-Hill.

Parasuraman, A., Zeithaml, V. A., \& Berry, L. L. (1988). SERVQUAL: A Multiple-Item Scale for measuring Consumer Perceptions of Service Quality. Journal of Retailing, 64(1), 14-40.

Pearce, D. (1989). Tourist Development. Wiley, New York.

Petrick, J. F. (2002). Development of a multi-dimensional scale for measuring the perceived value of service. Journal of Leisure Research, 34(2), 119-134.

Pike, S. (2004). Destination image analysis: a review of 142 papers from 1973 to 2000. Journal of Tourism management, 23(5), 541-549. http://dx.doi.org/10.1016/S0261-5177 (02)00005-5 
Pike, S., \& Ryan, C. (2004). Destination positioning analysis through a comparison of cognitive, affective, and $\begin{array}{llll}\text { conative perceptions. Journal of Travel Research, 42(4), 333-342. } & \end{array}$ http://dx.doi.org/10.1177/0047287504263029

Poon, A. (1993). Tourism, technology and competitive strategies. C.A.B.International, Wallingford Oxon.

Reilly, M. D. (1990). Free elicitation of descriptive adjectives for tourism image assessment. Journal of Travel Research, 28(1), 21-26. http://dx.doi.org/10.1177/004728759002800405

Research and market organization. (2009). Vietnam Tourism Industry Forecast to 2012. Retrieved from http://www.researchandmarkets.com/reports/694733/vietnam_tourism_industry_forecast_to2012

Robin, J. B., Ritchie, J. R., \& Brent, R. (2002). A framework for an industry supported destination marketing information system. Tourism Management, 23, 439-454. http://dx.doi.org/10.1016/S0261-5177(02)00007-9

Schumacker, R. E., \& Lomax, R. G. (2004). A beginner's guide to structural equation model (2nd ed.). Lawrence Erlbaum Associates, Mahwah.

Sirakaya, E., Petrick, J., \& Choi, H. S. (2004). The role of mood on tourism product evaluations. Annals of Tourism Research, 31(3), 517-539. http://dx.doi.org/10.1016/j.annals.2004.01.009

Smith, M. K. (2003). Issues in Cultural Tourism Studies. Routledge, London.

Stevens, B. F. (1992). Price Value Perceptions of travelers. Journal of Travel Research, 31(Fall), 44-48.

Tabachnick, B. G., \& Fidell, L. S. (2007). Using multivariate statistics (5th ed.). Pearson Education, Boston.

Teas, R. K. (1994). Expectations as a Comparison Standard in Measuring Service Quality: An Assessment of a Reassessment. Journal of Marketing, 581, 132-139.

Tian-Cole, S., Crompton, J. L., \& Willson, V. L. (2002). An empirical investigation of the relationships between service quality, satisfaction and behavioral intentions among visitors to a wildlife refuge. Journal of Leisure Research, 34(1), 1-24.

Tribe, J., \& Snaith, T. (1998). From SERVQAL to HOLSAT: holiday satisfaction in Varadero Cuba. Tourism Management, 19(1), 22-34. http://dx.doi.org/10.1016/S0261-5177(97)00094-0

Truong, T. H., \& King, B. (2009). An evaluation of satisfaction levels among Chinese tourists in Vietnam. International Journal of Tourism Research, 11(6), 521-535. http://dx.doi.org/10.1002/jtr.726

Truong, T. H. (2005). Assessing holiday satisfaction of Australian travelers in Vietnam: An application of the HOLSAT model. Asia Pacific Journal of Tourism Research, 10(3), 227-246. http://dx.doi.org/10.1080/10941660500309572

Truong, T. H., \& Foster, D. (2006). Using HOLSAT to evaluate tourist satisfaction at destinations: the case of Australia holidaymakers in Vietnam. Tourism Management, 27(5), 842-855. http://dx.doi.org/10.1016/j.tourman.2005.05.008

Turner, L., \& Reisinger, Y. (1999). Importance and expectations of destination attributes for Japanese tourists to Hawaii and the gold coast compared. Asia Pacific Journal of Tourism Research, 4(2), 1-18.

Um, S., \& Crompton, J. L. (1990). Attitude Determinants in Tourism Destination Choice. Annals of Tourism Research, 17(3), 432-448. http://dx.doi.org/10.1016/0160-7383(90)90008-F

Valle, O. D., Silva, S. A., Mendu, J., \& Guerreco, M. (2006). Tourist satisfaction and destination loyalty intention: structural and categorical analysis. International Journal of Business Science and Applied Management, 1(1), 25-44.

Wang, Y., \& Fesenmaier, D. (2005). dentifying the success factors of web-based marketing strategy: An investigation of convention and visitors bureaus in the United States. Journal of Travel Research, 43(3), $1-11$.

Weber, K. (1996). The Assessment of Tourist Satisfaction Using the Expectancy Disconfirmation Theory: A Study of the German Travel Market in Australia. Pacific Tourism Review, 14, 35-45.

Woodside, A. G., \& Lysonski, S. (1989). A General Model of Traveler Destination Choice. Journal of Travel Research, 27(4), 8-14.

Yüksel, A., \& Akgül, O. (2007). Postcards as affective image makers: An idle agent in destination marketing. Tourism Management, 28(3), 714-725. http://dx.doi.org/10.1016/j.tourman.2006.04.026 
Žabka, V., Brenc`ičn, M. M., \& Dmitrovic', T. (2010). Modeling perceived quality, visitor satisfaction and behavioral intentions at the destination level. Tourism Management, 31(4), 537-546. http://dx.doi.org/10.1016/j.tourman.2009.06.005

Zahra, I. (2012). Destination image and tourism: A case study of Bangladesh. European Journal of Business and Management, 4(6), 18-27.

\section{Note}

Note 1 . The reliability for the pilot test: Promotion activities (Cronbach's $\alpha=0.79$ ), Tourism expectation (Cronbach's $\alpha=0.72$ ), Tourist satisfaction (Cronbach's $\alpha=.91$ ) and Destination loyalty (Cronbach's $\alpha=0.82$ ). 